\title{
p75 Is Important for Axon Growth and Schwann Cell Migration during Development
}

\author{
Cornelia A. Bentley ${ }^{2}$ and Kuo-Fen Lee 1 \\ 1The Salk Institute, La Jolla, California 92037, and ${ }^{2}$ The Biomedical Sciences Graduate Program, University of California, La \\ Jolla, California 92093
}

\begin{abstract}
Mice lacking the low-affinity neurotrophin receptor p75 have multiple peripheral neural deficits. Here we examined the developmental nature of these deficiencies. Peripheral axons in p75 -l- embryos were severely stunted and poorly arborized from embryonic day 11.5 (E11.5) to E14.5. In vitro, neurite outgrowth from the dorsal root ganglia was significantly decreased in the p75 -/- embryos at E12.5, suggesting that stunted axonal growth in the embryo may result in part from defects in neurite elongation. Additionally, Schwann cell marker $\mathrm{S} 100 \beta$ immunoreactivity was decreased or absent along the growing axons of the ophthalmic branch from the trigeminal ganglia in p75 -/- embryos. Electron microscopy studies of the axons of the trigeminal
\end{abstract}

ganglion at E13.5 revealed that in the p75 mutant embryo, nerve bundles were highly impaired and that coverage of the growing axons by Schwann cell cytoplasm was substantially reduced. In vitro, Schwann cell migration from the dorsal root ganglia was significantly decreased in the p75 -/- embryos at E12.5, suggesting that the lack of $S 100 \beta$ staining and Schwann cell coverage in the p75 mutant results from a deficit in Schwann cell migration. These results provide evidence that $p 75$ is important in the developing embryo for regulating axon growth and arborization and for Schwann cell migration.

Key words: p75; Schwann cells; neurites; axons; development; peripheral nervous system; branching; electron microscopy
The neurotrophins play an important role in the development of the peripheral nervous system by modulating many cellular activities, including cell survival (Snider, 1994), neurite outgrowth, and axonal branching and morphology (Cohen-Cory and Fraser, 1995; Gallo and Letourneau, 1998; Cohen-Cory, 1999; Lom and CohenCory, 1999; McAllister et al., 1999). These effects of the neurotrophins may be mediated through two classes of receptors: the high-affinity tyrosine receptor kinase (trk) receptors (Bothwell, 1991; Chao, 1992; Kaplan and Miller, 1997) and the low-affinity receptor $\mathrm{p} 75$.

Targeted mutation of the p75 receptor gene shows that p75 is required for several aspects of peripheral sensory (Lee et al., 1992) and sympathetic (Lee et al., 1994a) innervation. Sympathetic innervation to the lateral footpads and the pineal gland is absent in the p75 mutant mouse (Lee et al., 1994a). More strikingly, the p75 mutant mice have a $50 \%$ loss of the sensory neurons of the dorsal root ganglia (DRG) affecting all classes of sensory neurons (Bergmann et al., 1997; Fundin et al., 1997; Rice et al., 1998; Fan et al., 1999; our unpublished data). Because p75 plays a role in peripheral innervation from diverse populations of neurons, including sensory and sympathetic, and in all classes of sensory neurons, a common mechanism may account for these losses of peripheral innervation. It is this hypothesis that led us to explore the developmental nature of the peripheral sensory deficiencies in the p75 mutant mouse.

p75 plays a role in many cellular activities, including cell survival (Davies et al., 1993; Barrett and Bartlett, 1994; Lee et al., 1994b), cell death (Rabizadeh et al., 1993; Barrett and Bartlett, 1994; Casaccia-Bonnefil et al., 1996; Frade et al., 1996; Bamji et al., 1998), and Schwann cell migration (Anton et al., 1994). A general role for p75 in neural development is supported by the ability of p75 to bind all neurotrophins (Rodríguez-Tébar et al., 1990, 1992)

\footnotetext{
Received Dec. 28, 1999; revised Aug. 3, 2000; accepted Aug. 8, 2000.

This work was supported by grants from National Institutes of Health (HD34534 and AG10435) and the March of Dimes Foundation. K.F.L. is a Pew Scholar. We thank J. Morris, J. Pitman, and T.-C. Sung for critical reading of this manuscript. We are also grateful to J. Morris for advice on the Schwann cell migration assay. We thank the Electron Microscopy Core at the Veterans Administration Hospital, University of California San Diego for excellent technical support. Thanks to Susan Fitzpatrick for editorial assistance.

Correspondence should be addressed to Dr. Kuo-Fen Lee, The Salk Institute, 10010 N. Torrey Pines Road, La Jolla, CA 92037. E-mail: klee@salk.edu.

Copyright (C) 2000 Society for Neuroscience $0270-6474 / 00 / 207706-10 \$ 15.00 / 0$
}

along with its broad expression in all classes of sensory neurons (Yan and Johnson, 1988; Wright and Snider, 1995), Schwann cells (Taniuchi et al., 1988), and target tissues (Wheeler and Bothwell, 1992). On the basis of this expression pattern, p75 may influence innervation and axonal morphology through axon-target interaction, axon-Schwann cell interaction, and Schwann cell migration. Molecular cues within target tissues expressed in an age-dependent fashion have been shown to regulate axonal morphology (Erzurumlu and Jhaveri, 1995). Target-derived neurotrophins, e.g., BDNF, are indeed capable of promoting axonal branching (CohenCory and Fraser, 1995; Gallo and Letourneau, 1998; Cohen-Cory, 1999; Lom and Cohen-Cory, 1999). Axons therefore must be able to respond to these target-derived molecular cues and be in the appropriate target locations to receive adequate levels of exposure to these factors. Because p75 has been shown to signal independently (Anton et al., 1994; Dobrowsky et al., 1995; Carter et al., 1996; Frade et al., 1996; Yamashita et al., 1999) and in collaboration with the trk receptors (Davies et al., 1993; Barker and Shooter, 1994; Hantzopoulos et al., 1994; Lee et al., 1994b; Verdi et al., 1994; Huber and Chao, 1995; Wolf et al., 1995; Twiss et al., 1998; Brennan et al., 1999), p75 may support peripheral nerve development through a number of probable mechanisms. p75 may act in the development of the peripheral nervous system by independently binding and responding to target-derived neurotrophins, mediating the binding and response of the trks to target-derived neurotrophins, or more indirectly by affecting axon growth such that it is in the appropriate target area to receive target-derived molecular cues.

p75 may also affect the development of the peripheral nervous system through regulation of Schwann cell migration. Several studies demonstrate the importance of Schwann cells for axonal morphology and neuronal survival. Targeted deletion of the erbB2 and erbB3 genes in mice, resulting in the absence of Schwann cells in the periphery, leads to defasciculation (Morris et al., 1999), neural degeneration, and ultimately neuronal loss (Riethmacher et al., 1997; Morris et al., 1999; Woldeyesus et al., 1999). Furthermore, Schwann cells have been shown to be important for neurite outgrowth (Zimmermann and Sutter, 1983; Bixby et al., 1988). Bidirectional signaling occurs between developing axons and Schwann cells (Jessen and Mirsky, 1991). Schwann cells can therefore regulate axonal growth, and axons can in turn regulate 
Schwann cell migration (Bhattacharyya et al., 1994). p75 may play a role in this dynamic interaction during development because it is expressed in both neurons and Schwann cells (Taniuchi et al., 1988) and has been shown to modulate Schwann cell migration from neonatal rat DRG (Anton et al., 1994). The present study suggests that p75 promotes peripheral nerve development by regulating both Schwann cell and axonal growth aspects of innervation.

\section{MATERIALS AND METHODS}

Animals and genotype analysis. p75 mutant mice were maintained on a mixed 129/Balbc/c background (Lee et al., 1992). In most cases, embryos were obtained from heterozygote $(+/-)$ intercrosses. Occasionally, mutant embryos were obtained from homozygote $(-/-) \times$ heterozygote $(+/-)$ crosses, whereas control embryos were obtained from wild-type $(+>+) \times$ wild-type $(+/+)$ crosses. Mice were housed using standard conditions, and the use of mice is in compliance with the guidelines of Institute Animal Care and Use Committee of the Salk Institute. E11.5-E14.5 embryos were removed and washed in HEPES buffer. Yolk sac DNA was isolated for PCR genotyping.

The primers used for p75 PCR analysis were as follows: p75-1, 5'CGATGCTCCTATGGCTACTA3'; p75-2, 5'CCTCGCATTCGGCGTCAGCC3'; and PGK, 5'GGGAACTTCCTGACTAGGGG3'. Each $20 \mu \mathrm{l}$ PCR reaction contains $0.4 \mu \mathrm{l}$ of $10 \mathrm{mM}$ dNTPs, $2.0 \mu \mathrm{l}$ of $10 \times$ PCR buffer, $0.5 \mu \mathrm{l}$ each of $20 \mu \mathrm{M}$ p75-1 primer, p75-2 primer, and PGK primer, $1.2 \mu \mathrm{l}$ of $25 \mathrm{~mm}$ $\mathrm{MgCl}_{2}, 1.0 \mu \mathrm{l}$ of DNA, and $0.15 \mu \mathrm{l}$ of $5 \mathrm{U} / \mu \mathrm{l}$ Taq. The following PCR conditions were used: 30 cycles of $1 \mathrm{~min}$ at $94^{\circ} \mathrm{C}, 1 \mathrm{~min}$ annealing at $56^{\circ} \mathrm{C}$, and $1 \mathrm{~min}$ at $72^{\circ} \mathrm{C}$ followed by a single $10 \mathrm{~min}$ extension at $72^{\circ} \mathrm{C}$. Primers p75-1 and p75-2 yielded a 247 bp product for the wild-type allele. Primers p75-1 and PGK produced a 317 bp product for the mutant allele.

Whole-mount immunohistochemistry using diaminobenzidene. Peripheral innervation was visualized at E11.5, E12.5, E13.5, and E14.5 using antibodies against neurofilament (NF150 or NF-M) (Chemicon, Temecula, $\mathrm{CA}$; both at a dilution of 1:500). All incubations were performed on a slow shaker table. Embryos were collected and fixed in $4 \%$ paraformaldehyde (PFA) in PBS overnight. Embryos were then eviscerated, rinsed briefly in PBS, and bleached overnight at $4^{\circ} \mathrm{C}$ in Dent's fix $(4: 1$, methanol/DMSO) containing $5 \%$ hydrogen peroxide. Bleaching was then allowed to continue for $3 \mathrm{hr}$ at room temperature. Samples were blocked overnight at room temperature in dilution buffer $(0.5 \mathrm{M} \mathrm{NaCl}, 0.01 \mathrm{M}$ phosphate buffer, $\mathrm{pH}$ $7.3,3 \%$ bovine serum albumin, $0.1 \%$ sodium azide, and $0.3 \%$ Triton $\mathrm{X}-100$ ) containing $5 \%$ goat serum and $1 \%$ DMSO. Blocking buffer (dilution buffer containing 5\% goat serum and 1\% DMSO) was then replaced with fresh blocking buffer containing neurofilament antibodies (NFM or NF150). After $2 \mathrm{~d}$ at room temperature, samples were washed three times for $1 \mathrm{hr}$ each in Tris-buffered saline (TBS) containing 1\% Tween-20 (TBST) and $1 \%$ DMSO. Horseradish peroxidase-conjugated goat antirabbit secondary antibody (Vector, Burlingame, CA; 1:1000) in dilution buffer was added and incubated overnight at room temperature. The samples were washed three times for $1 \mathrm{hr}$ each in TBST $+1 \%$ DMSO and then once in TBS for $1 \mathrm{hr}$. The diaminobenzidine (DAB) reaction was catalyzed by $50 \mathrm{U}$ of glucose oxidase (Calbiochem, La Jolla, CA). One hundred milliliters of the DAB reaction solution contained $0.4 \mathrm{D}$-glucose, $0.04 \mathrm{gm}$ ammonium chloride, $0.135 \mathrm{gm}$ imidazole, $0.05 \mathrm{gm}$ DAB, $10 \mathrm{~m}$ $10 \times$ TBS, and $90 \mathrm{ml}$ water. The reaction was allowed to proceed no more than $45 \mathrm{~min}$. The samples were then washed briefly in TBS, dehydrated in graded methanol, and cleared in glycerol for 1-2 $\mathrm{d}$.

Fluorescent whole-mount immunohistochemistry. The embryos were fixed in $2 \%$ PFA in PBS at $4^{\circ} \mathrm{C}$ overnight. All incubations were performed on a slow shaker table. The following day, the skin above the eye together with the eye were dissected and rinsed briefly in PBS. The eye served as a point of orientation for axon morphology. The skin samples were blocked overnight at $4^{\circ} \mathrm{C}$ in blocking buffer (dilution buffer containing $5 \%$ goat serum). Blocking buffer was removed and replaced with blocking buffer containing mouse anti-TuJ1 [unique $\beta$-tubulin ( $\beta \mathrm{III}$ ); Babco (Richmond, VA); dilution 1:500] and rabbit anti-S100 $\beta$ antibodies (Swant, Bellinzona, Switzerland; dilution 1:1000). The tissues were incubated overnight at $4^{\circ} \mathrm{C}$ and then washed three times for $1 \mathrm{hr}$ each in PBS containing $0.5 \%$ Triton X-100 (PBST). Secondary antibodies goat anti-mouse IgG (Fab') TRITC conjugate (Sigma, St. Louis. MO; 1:500) and goat anti-rabbit IgG F(ab') cy3-conjugated (Jackson, West Grove, PA; 1:600) were added in dilution buffer. The samples were incubated overnight at $4^{\circ} \mathrm{C}$, washed three times for $1 \mathrm{hr}$ each in PBST, and washed once for $1 \mathrm{hr}$ in PBS. Finally, after the eye was removed, the skin was flat-mounted in $90 \%$ glycerol, polyvinyl alcohol, and $N$-propyl gallate. Skin preparations were imaged using confocal microscopy with scanning lasers (Olympus Fluoview).

Neurite outgrowth and Schwann cell migration assays. Migration of Schwann cells and neurite outgrowth from DRG were quantitatively assayed as described previously (Tuttle and Matthew, 1991; Morris et al., 1999). Briefly, E12.5 DRG were dissected out in L15 medium (Life Technologies, Grand Island, NY), treated with collagenase (type CLS, Worthington Biochemical, Freehold, NJ) [1 mg/ml in RPMI medium 1640 (Life Technologies) for $20 \mathrm{~min}$ at $37^{\circ} \mathrm{C}$ ] to remove capsule, and placed on a $20 \mu \mathrm{m}$ adult sciatic nerve cryosection. Before culturing the DRG, cryosections were mounted on glass coverslips, allowed to dry at room temperature for $1 \mathrm{hr}$, placed in $35 \mathrm{~mm}$ Petri dishes, and then washed three times in RPMI with the third wash left on nerve sections for at least $1 \mathrm{hr}$ at $37^{\circ} \mathrm{C}$. The DRG were cultured for $3 \mathrm{~d}$ in RPMI/10\% FBS with BSA or NGF $(5 \mathrm{ng} / \mathrm{ml})$. The medium was then replaced with vital dye $10 \mathrm{~mm}$ 5(6)-carboxyfluorescein diacetate succinimidyl ester (Molecular Probes, Eugene, OR) and incubated for $5 \mathrm{~min}$. The cultures were immediately photographed. In the presence of BSA, only Schwann cells or Schwann cell precursors migrate along the sciatic nerve. This was confirmed by immunohistochemistry with erbB3 antibodies (Morris et al., 1999), a marker for Schwann cell precursors. The addition of NGF promotes neurite outgrowth. Schwann cell migration and neurite outgrowth were quantified by directly measuring the distance form the leading edge of the DRG to the farthest Schwann cell or neurite on $35 \mathrm{~mm}$ photographic negatives taken of vital dye-stained cultures.

The preceding protocol was modified to assess Schwann cell migration in the presence of NGF. E12.5 DRGs were placed on a sciatic nerve cryosection at a "starting line," which had been previously marked with a permanent marker on the bottom side of the glass coverslip. Schwann cells were allowed to migrate onto the sciatic nerve sections for $36 \mathrm{hr}$. The DRG were then removed by cutting away both the sciatic nerve and DRG at the starting line. The RPMI medium was then replaced with fresh RPMI with or without $10 \mathrm{ng} / \mathrm{ml}$ of NGF. Schwann cell migration was then allowed to proceed for $72 \mathrm{hr}$. Schwann cell migration was measured by the distance of the furthest Schwann cell from the leading edge of the starting line on 35 $\mathrm{mm}$ photographic negatives taken of vital dye-stained cultures. An additional phase photograph was taken to pinpoint the location of the starting line. Schwann cell migration and neurite distances are expressed as mean \pm SEM. Statistical significances of differences were tested using the Student's $t$ test.

Electron microscopy. Under a dissecting microscope, skin above the eye innervated by the trigeminal ganglia from E13.5 control $(n=2)$ and mutant $(n=2)$ embryos was removed in cold $\left(4^{\circ} \mathrm{C}\right)$ Karnovsky's buffered $\mathrm{pH} 7.4$ fixative. After fixation, samples were then washed three times in cold $\left(4^{\circ} \mathrm{C}\right) 0.1 \mathrm{M}$ sodium cacodylate buffer, $\mathrm{pH}$ 7.4. After three buffer washes, the tissues were post-fixed in sodium cacodylate-buffered ( $\mathrm{pH} 7.4)$ $2 \%$ osmium tetroxide for $1 \mathrm{hr}$ at room temperature. After three buffer washes of $5 \mathrm{~min}$ each, the tissues were dehydrated through a graded series of ethanol and propylene oxide and embedded in plastic resin (EM-bed 812, EM Sciences, Fort Washington, PA).

Serial thick sections $(1-2 \mu \mathrm{m})$ of all tissue blocks for light microscopy were stained with $1 \%$ toluidine blue. From these sections, nerve tracts were identified, and ultrathin sections were cut $(60 \mathrm{~nm})$, mounted on $200 \mathrm{mesh}$ unsupported copper grids, and stained in uranyl acetate and bismuth subnitrate.

\section{RESULTS}

\section{Peripheral nerves are severely stunted in p75 $-/-$ embryos}

p75 is important for sensory innervation from the DRG (Lee et al., 1992) and sympathetic innervation from the sympathetic ganglia (Lee et al., 1994a). To understand how p75 affects the morphology of these diverse populations of neurons during development, we examined neurofilament (NF) staining of the peripheral nerves between E11.5 and E14.5 in the p75 mutant (p75 -/-) mice (Lee et al., 1992). Because no differences were noticed between p $75+/+$ and p75 +/ - embryos, both groups were used as controls. Wholemount immunohistochemistry allowed us to visualize the morphology of axons in the limbs using antibodies against NF. These visually accessible regions showed striking differences between p75 $-/-$ and control animals. p75 $-/-$ mice exhibited increasing deficiencies of innervation to the forelimbs (Fig. 1) as they developed from age E11.5 to E14.5. At E11.5 $(n=3)$, NFimmunopositive axons in the forelimb of p $75-/-$ embryos did not extend as far into the limb as those in the control littermates and appeared less branched (Fig. $1 A, B$ ). By E12.5 (control, $n=8$; p75 $-/-, n=7)$, the differences between limb innervation in mutant and control embryos were more dramatic. Branching in the forelimbs of E12.5 control embryos became quite extensive, whereas axons in the limbs of the mutants had not arborized and appeared stunted (Fig. 1C,D). NF-immunopositive axons were well arborized across much of the developing limbs of control embryos at E13.5 (p75 +/-, $n=3$; p75 -/-, $n=2)$, whereas axons in the limbs of p75 mutant embryos were less elaborate and visible only in the most proximal regions (Fig. $1 E, F)$. Finally, at E14.5 $(n=3)$ the forelimbs and digits of control embryos were highly innervated with well arborized axons (Fig. $1 G$ ). The forelimbs of p75 -/- embryos, however, showed almost no immunopositive axonal innervation (Fig. $1 H$ ). Although the deficiency of axon growth was severe in the 


\section{$+/+$ or $+/-$}
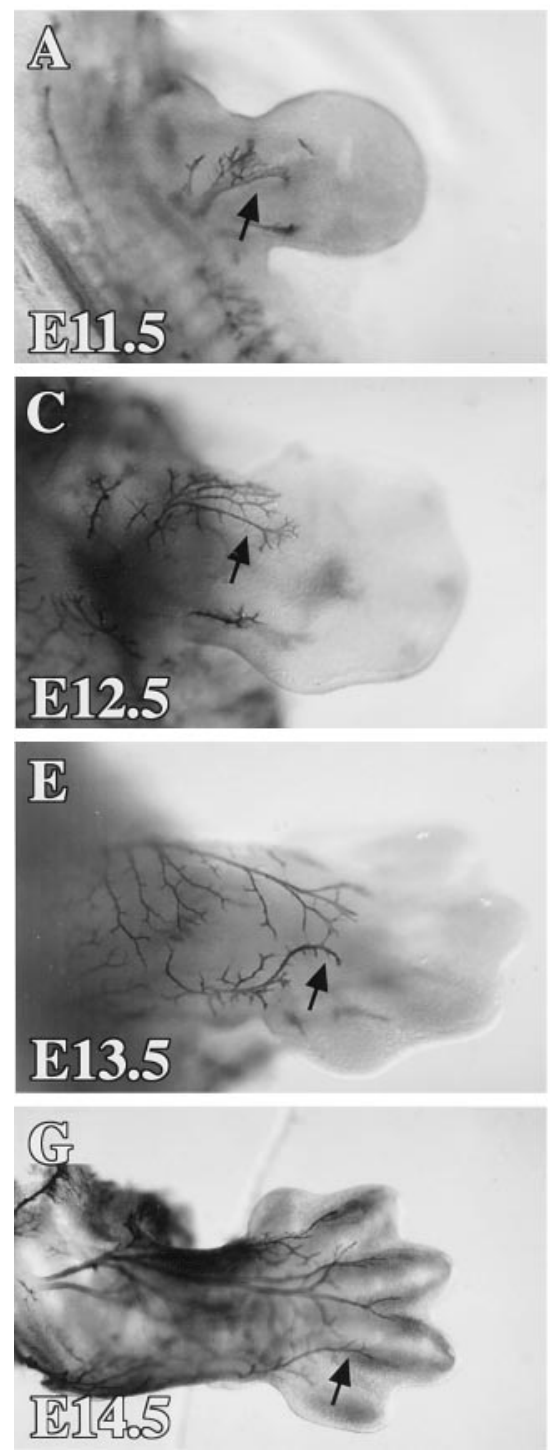

$-/-$
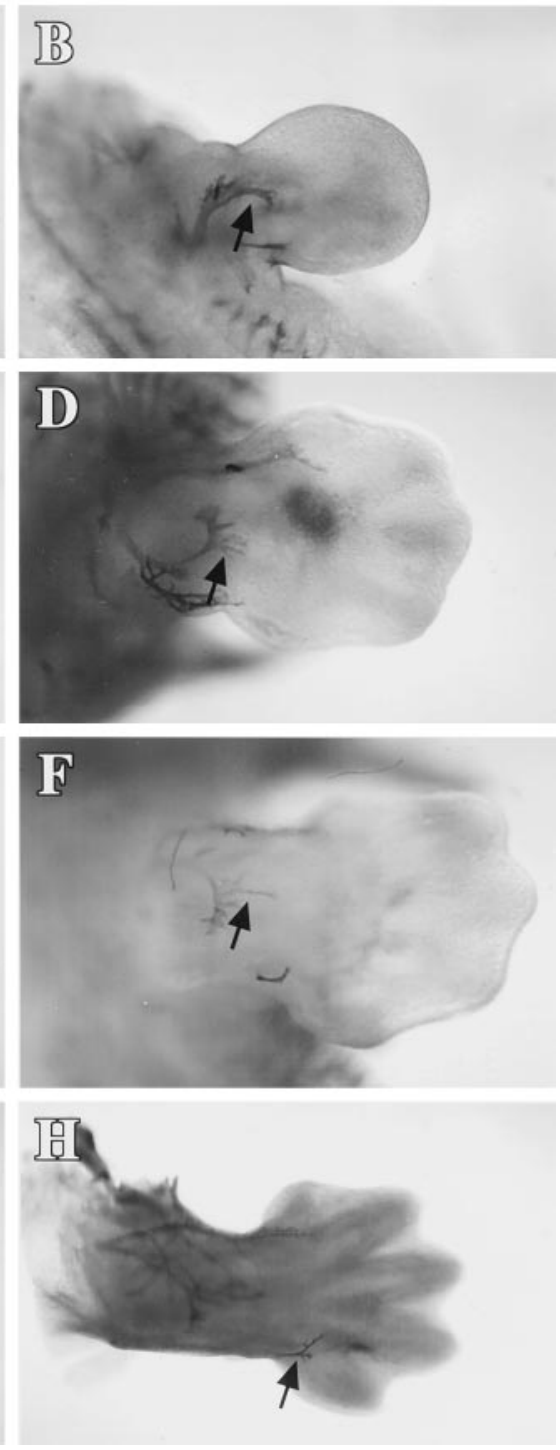

Figure 1. Whole-mount immunohistochemistry for neurofilament shows that innervation of the developing limbs is decreased in the p $75-/-$ embryos. Shown is a dorsal view of the forelimbs of controls $(A, C, E, G)$ and p75 mutants $(B$, $D, F, H)$ at ages E11.5 $(A, B), \mathrm{E} 12.5(C, D), \mathrm{E} 13.5(E, F)$, and E14.5 $(G, H)$. Arrows indicate immunoreactive axons projecting into the forelimbs. Photographs of whole mounts were taken using a dissecting microscope at $40 \times$ magnification.

limbs, innervation of the vibrissae, another visually accessible area, was not notably impaired in the mutants (data not shown).

To further assess what types of axons are predominantly visible in the limbs, we also performed whole-mount immunohistochemistry for tyrosine hydroxylase (TH) to label the sympathetic neurons at E12.5, E13.5, and E14.5. As expected, the sympathetic chain was labeled along with fibers emerging from the sympathetic ganglia. No TH-labeled fibers were observed in the limbs at any of the ages examined (data not shown). Although at this young age the possibility that some of the fibers visualized by the NF staining are motor cannot be ruled out, we believe that they are most likely sensory because of the superficial location of the NF-stained fibers.

Innervation to the skin above the eye originates from the trigeminal ganglion (TG). This ganglion also shows a loss of neuronal number in the p75 mutant mice (Walsh et al., 1999). The translucency of this region allowed us to closely follow axon growth and morphology of these sensory nerves in developing p $75-/-$ embryos. Whole-mount immunohistochemistry with antibodies against neurofilament, in the p75 mutant mice at E11.5-E14.5, showed stunted neurite processes and a profound lack of arborization in axons extending from the TG to the skin anterior to the eye (Fig. 2). At E11.5 $(n=3)$, innervation around the eye was barely visible in both control and p75 - /- embryos (Fig. $2 A, B$ ). Already at E12.5 (control, $n=8$; p75 -/-, $n=7$ ), the control embryos showed more arborization of the axons above the eye than the mutant littermates (Fig. 2C,D). Immunopositive axons in the skin above the eye in the control animals developed extensive branching at E13.5 (p75 +/-, $n=3$; p75 -/-, $n=2)$, whereas axons in the mutants were still largely unarborized and severely stunted (Fig. $2 E, F)$. At E14.5 $(n=3)$, immunostaining showed that axons remained stunted in the p75 mutants and had failed to arborize (Fig. 2G,H). These data demonstrate a role for p75 in axon growth and morphology of several types of sensory neurons, including DRG neurons innervating the limbs and TG neurons innervating the skin of the head.

\section{Neurite outgrowth from the DRG of p75 -/- embryos was decreased in vitro}

Because nerves are severely stunted in the p75 mutant embryo, we wanted to test neurite outgrowth function. Neurite outgrowth assays were performed using cervical DRG from E12.5 p75 +/+, $+/-$, and $-/-$ embryos. This assay uses neurons that are most likely impaired as visualized from NF staining, and it has been shown to mimic in vivo conditions (Sandrock and Matthew, 1987; Tuttle and Matthew, 1991; Morris et al., 1999). After $72 \mathrm{hr}$ in culture in the presence of $5 \mathrm{ng} / \mathrm{ml} \mathrm{NGF}$, neurite outgrowth along sciatic nerve cryosections was measured from the leading edge of the DRG to the farthest neurite visualized with vital dye. Neurite 


\section{$+/+$ or $+/-$}
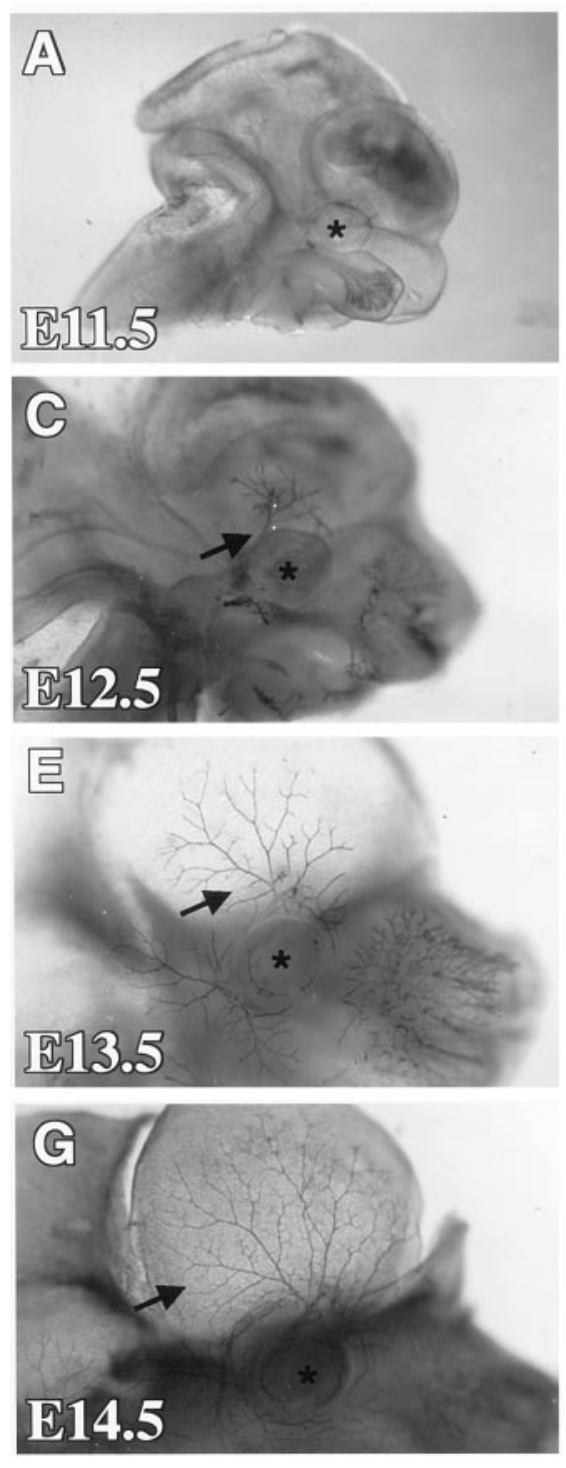
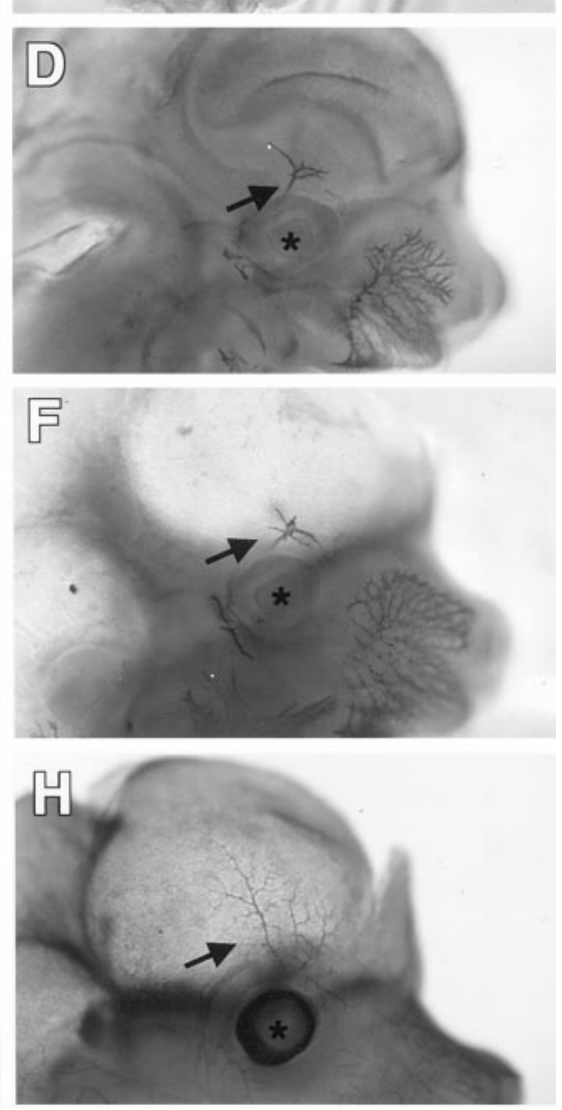

Figure 2. Neurofilament whole-mount immunohistochemistry of the skin from the head of developing embryos shows that axons of the ophthalmic branch of the TG are less extensive and complex in the p75 -/- embryos. Shown is a sagittal view of the head in the controls $(A, C, E, G)$ and 75 mutants $(B, D, F, H)$ at ages E11.5 $(A, B)$, E12.5 $(C, D)$, E13.5 $(E, F)$, and E14.5 $(G, H)$. The contralateral side of the head and the brain have been removed in $E-H$ to increase transparency of the skin. Asterisks indicate location of the eye. Arrows point to axons of the ophthalmic branch. Photographs of whole mounts were taken using a dissecting microscope at $40 \times$ magnification.

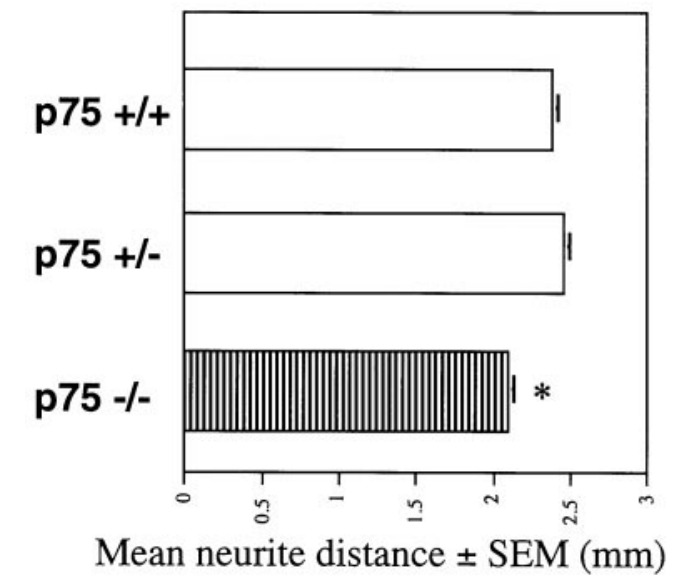

outgrowth culture assays were performed at least five times, and the results were pooled. Neurite outgrowth from the E12.5 DRG of p75 - / - embryos was decreased by $12 \%$ compared with that of $+/+$ controls $(\mathrm{p} 75+/+, 2.38 \pm 0.04 \mathrm{~mm}, n=108$; p75 -/-, $2.09 \pm$ $0.05 \mathrm{~mm}, n=50 ; p<0.0001$ ) (Fig. 3). Neurite outgrowth from the DRG of p75 - /- embryos compared with outgrowth from the
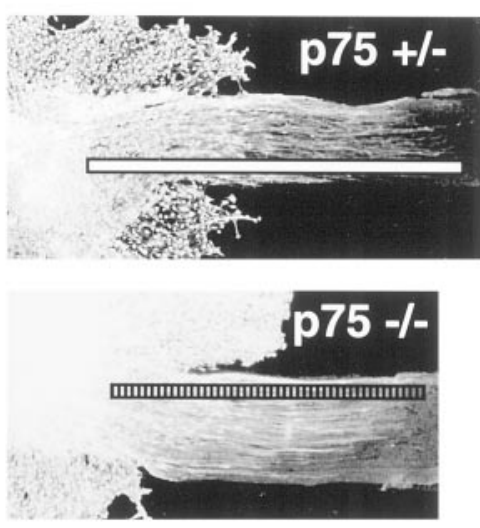

Figure 3. In vitro neurite outgrowth from the DRG of control and p75 -/- embryos. Bar graph shows mean distance $(\mathrm{mm})$ of neurite outgrowth and SEM in the presence of NGF $(5 \mathrm{ng} / \mathrm{ml})$ from the DRG of p75 $+/+,+/-$, and $-/-$ embryos. Mean neurite outgrowth distance from the DRG of p75-/- embryos is significantly lower (asterisk) than the outgrowth distances from the DRG of both $\mathrm{p} 75+/+$ $(p<0.0001)$ and $\mathrm{p} 75+/-$ embryos $(p<0.0001)$. Representative micrographs showing vital dye staining of the DRG and extended neurites are overlaid with a line demonstrating measurement of neurite outgrowth distance.
DRG of p75 +/- embryos was decreased by $15 \%(\mathrm{p} 75+/-, 2.46 \pm$ $0.04 \mathrm{~mm}, n=82 ; p<0.0001$ ) (Fig. 3). There was not a statistically significant difference in neurite outgrowth from the DRG of p75 $+/+$ and p75 +/- embryos. These data suggest that impaired neurite outgrowth may be responsible in part for the stunted axon growth in the p75 mutant embryo. 

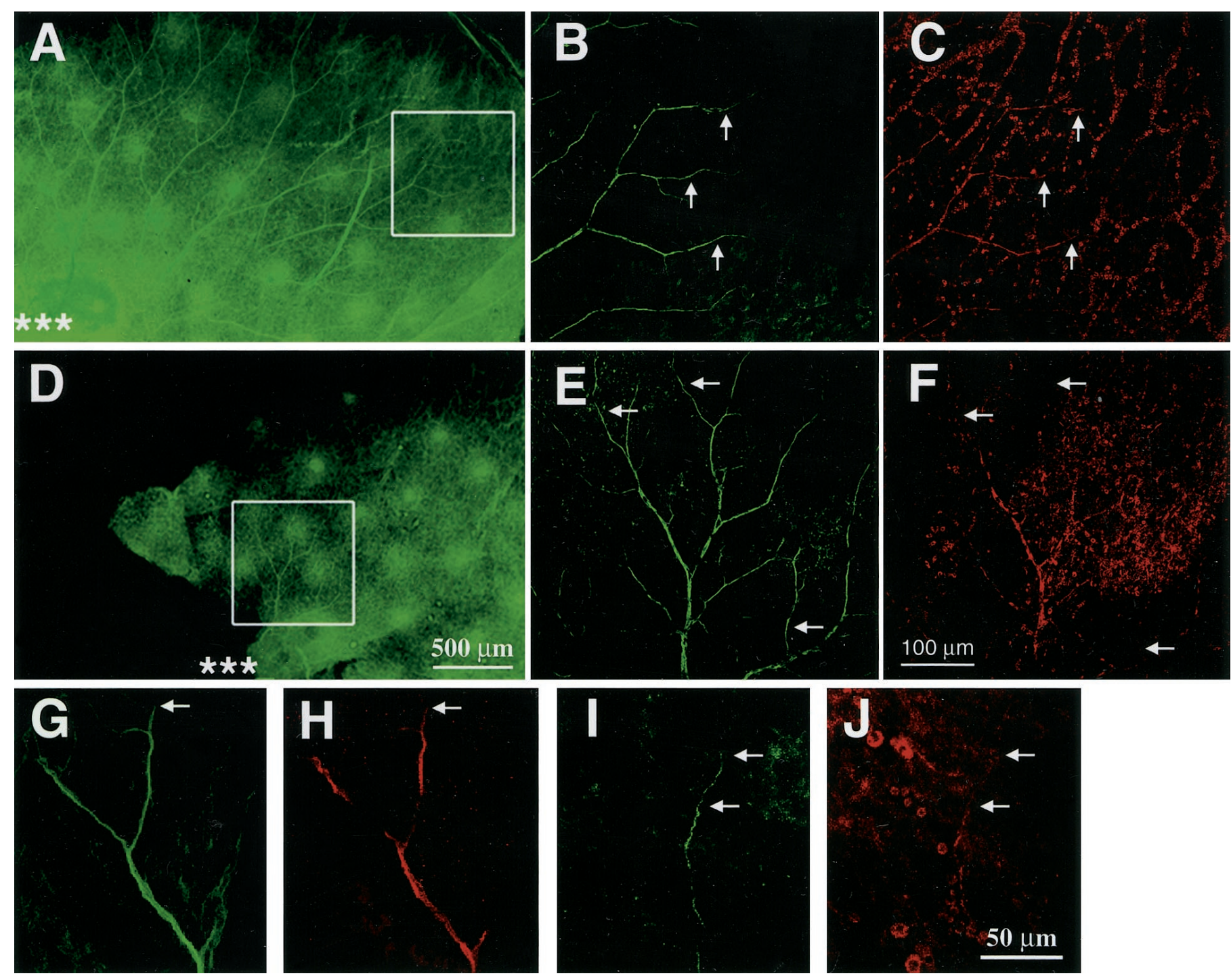

Figure 4. Whole-mount double immunohistochemistry using antibodies against $\mathrm{S} 100 \beta$ and TuJ1 to visualize the ophthalmic branch and associated Schwann cells of the TG in E14.5 embryos. Axons immunopositive for TuJ1 (green) are first shown at low-power magnification $(A, D$; scale bar, $500 \mu \mathrm{m})$. Asterisks in $A$ and $D$ indicate where the TG axons emerge above the eye. The white boxes in $A$ and $D$ show regions visualized at high-power magnification in $B, C$ and $E, F$, respectively (scale bar, $100 \mu \mathrm{m})$. Axons in the p75 mutants $(D-F)$ are severely stunted and less branched than those of the controls $(A-C)$. $\mathrm{S} 100 \beta$-staining $(r e d)(C, F)$ appears to colocalize with TuJ1 staining $(B, E)$. Arrows point out strong $\mathrm{S} 100 \beta(C)$ and $\mathrm{TuJ} 1(B)$ immunoreactivity in distal regions of axons in the control embryos. However, axons in the p75-/- embryos have several regions of decreased or absent S100 $\beta$ staining (arrows in $E, F)$. Higher-power magnification (scale bar, $50 \mu \mathrm{m}$ ) of axons in controls $(G, H)$ shows robust staining of S100 $\beta(H)$ ) even at the distal tip (arrows in $G$, $H)$ of the TuJ1-stained axons $(G)$. Higher-power magnification of axons in p $75-/-$ embryos $(I, J)$ shows that S100 $\beta$ staining $(J)$ is absent at the distal tip of the TuJ1-positive $(I)$ axons (top arrow in $J, I$ ) but can be seen more proximal to the TG (bottom arrow in $J, I$ ).

\section{Schwann cell marker $\mathrm{S} 100 \beta$ is decreased or absent along the ophthalmic branch of the TG in p75 -/- embryos}

p75 is expressed in Schwann cells (Taniuchi et al., 1988) and has been shown to play a role in neonatal Schwann cell migration (Anton et al., 1994). Because Schwann cells that support the axons of the TG must migrate out from the TG along with the axons, we wanted to examine the in vivo topology of these Schwann cells. The thin and transparent nature of the embryonic skin, innervated by the ophthalmic branch of the TG, provides an experimental approach to examine Schwann cells along the extending axons. A mouse antibody against tubulin ( $\mathrm{TuJ} 1)$ was used to visualize axons, and a rabbit antibody against $\mathrm{S} 100 \beta$ was used to mark Schwann cells in E14.5 (p75 +/+, $n=3$; p75 +/-, $n=6$; p75 -/-, $n=6)$ skin from $\mathrm{p} 75+/+,+/-$, and $-/-$ embryos. Imaging of double immunohistochemistry in skin whole mounts was accomplished using confocal microscopy. No differences were observed between p75 $+/+$ and $+/-$ animals. At E14.5, S100 $\beta$ staining was less frequently associated with the distal tips of the tubulin- immunoreactive axons in p75 mutant embryos (Fig. 4). These observations were quantified by measuring the distance from the tip of the tubulin-positive neurite to the first $\mathrm{S} 100 \beta$-positive Schwann cell (Fig. 5) in skin from control and mutant embryos. Three to five axons from each sample (controls, 11 samples with 48 axons measured; mutants, 10 samples with 45 axons measured) were randomly selected, viewing only the tubulin staining. The $\mathrm{S} 100 \beta$ staining was then visualized to make the measurements. In control samples, $70 \%$ of $\mathrm{S} 100 \beta$ staining was within $10 \mu \mathrm{m}$ of the tubulin-stained tip of the axon, whereas only $40 \%$ of S100 $\beta$ staining from samples of p75 -/- embryos was within $10 \mu \mathrm{m}$. S100 $\beta$ positive Schwann cells were rarely measured $>40 \mu \mathrm{m}$ from the visible tip of the axon (6\%) in samples from control embryos; in contrast, nearly $20 \%$ of Schwann cell/neurite distances measured in the mutants were $>40 \mu \mathrm{m}$. In addition, at E14.5, there was a dramatic loss of S100 $\beta$ staining over extended lengths of tubulinpositive axons in the skin of the mutants (Fig. $5 E, F)$. The intensity of $\mathrm{S} 100 \beta$ immunostaining in the E14.5 mutants was qualitatively decreased. A 2.5-fold greater laser intensity was required to visu- 


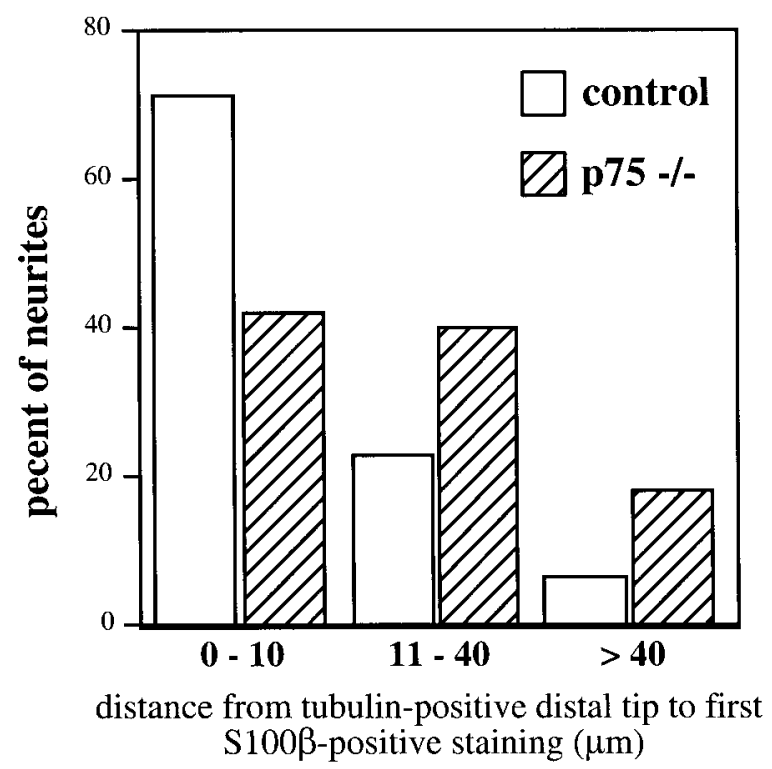

Figure 5. Analysis of $\mathrm{S} 100 \beta$ immunoreactivity in relation to the distal tips of tubulin-positive TG axons. Confocal images were used to measure the distance from the tip of the tubulin-positive axon to the nearest S100 $\beta$ immunoreactive Schwann cell at E14.5. Three to five tubulin-positive tips were randomly chosen for measurement in control $(n=48)$ and mutant $(n=45)$ skin samples. The results of measurements are summarized.

alize $\mathrm{S} 100 \beta$ immunoreactivity in samples from $\mathrm{p} 75$ mutant animals. The loss of $\mathrm{S} 100 \beta$ immunofluorescence along the developing axons of the TG in p75 mutants suggests that p75 is important for Schwann cell function and development in vivo or has secondary effects on cellular activities associated with $\mathrm{S} 100 \beta$ expression in Schwann cells.

\section{Schwann cell ensheathment of the developing axons is decreased at the ultrastructural level}

Loss of $\mathrm{S} 100 \beta$ immunoreactivity suggests that p75 -/- embryos may have fewer Schwann cells along their developing axons or that Schwann cells express less S100 $\beta$. To address this issue, we used electron microscopy to examine Schwann cells along developing axons in p75 mutant embryos. Skin above the eye innervated by the TG from E13.5 p75 +/- and p75 - /- embryos was used. Tissue was sectioned with the plane of the skin to produce a roughly longitudinal view of axons with their associated Schwann cells. Sections were taken from regions highest in neurite density to improve chances of finding axons by electron microscopy. We estimate this area of highest density to be relatively proximal to the eye (Fig. $2 E, F)$. Electron microscopy was performed on several nerves from control and p75 mutant embryos. Axon bundles in the p75 - / - embryos appeared disorganized and smaller than those of control embryos (Fig. 6). In control embryos, Schwann cell cytoplasm was always seen to completely encase the axon bundle. Frequently, large regions of axon bundles were bare of Schwann cell cytoplasm in the p $75-/-$ embryos. These results demonstrate that the developing axons in p75 mutant embryos have less ensheathment of the developing nerves by Schwann cells.

\section{Schwann cell migration from the DRG of p75 -I- embryos was decreased in vitro}

p75 is strongly expressed in the membrane of Schwann cell cytoplasmic processes in several tissues (Taniuchi et al., 1988; Byers, 1990), putting it in position to regulate Schwann cell-axon interaction. Schwann cells and axons interact bi-directionally during axonal growth (Jessen and Mirsky, 1991) to regulate Schwann cell migration (Bhattacharyya et al., 1994) and neurite outgrowth (Zimmermann and Sutter, 1983; Bixby et al., 1988). Schwann cell migration therefore may contribute to axonal morphology (Morris et al., 1999). To investigate the nature of the Schwann cell defects seen in vivo, we assayed the capability of Schwann cells from p75 mutant embryos to migrate in vitro.

Schwann cell migration assays were performed using cervical DRG from E12.5 p $75+/+,+/-$, and $-/-$ embryos. After $72 \mathrm{hr}$ in culture, Schwann cell migration along sciatic nerve cryosections was measured from the leading edge of the DRG to the farthest Schwann cell as visualized with vital dye. The Schwann cell migration distance results from at least three experiments were pooled, and measurements were comparable across experiments. Schwann cell migration from the DRG of E12.5 p75 -/- embryos was decreased by $15 \%$ compared with migration from the DRG of $\mathrm{p} 75$ $+/+$ embryos (p75 +/+, $1.99 \pm 0.04 \mathrm{~mm}, n=88$; p75 -/-, $1.7 \pm$ $0.06 \mathrm{~mm}, n=49 ; p<0.001$ ) (Fig. $7 A$ ). Schwann cell migration from the DRG of $75-/-$ embryos compared with migration from the DRG of $\mathrm{p} 75+/-$ was decreased by $11 \%(\mathrm{p} 75+/-, 1.91 \pm 0.05$ mm, $n=71 ; p=0.01$ ) (Fig. 7A). The difference in Schwann cell migration between $+/+$ and $+/-$ cultures was not statistically significant.

Schwann cell migration from P1 rat DRG can be decreased in the presence of antibodies against NGF (Anton et al., 1994). This implies that NGF binding to p75 may affect Schwann cell migration. To test how p75 may affect Schwann cell migration from embryonic DRG in the presence of NGF, without interference from NGF-induced neurite outgrowth, the Schwann cell migration assay was modified. E12.5 DRG were again cultured on sciatic nerve cryosections. Schwann cells were allowed to migrate onto the sciatic nerve sections for $36 \mathrm{hr}$. The DRG were then removed by cutting away the sciatic nerve at the DRG. The medium was then replaced with fresh medium, with or without NGF $(10 \mathrm{ng} / \mathrm{ml})$. Schwann cell migration was then allowed to proceed for $72 \mathrm{hr}$. This culture assay was repeated four times. Groups of the same genotype performed similarly in each experiment. A comparison of Schwann cell migration from the DRG of p75 $+/-$ and $+/+$ embryos revealed no differences (p75 +/+ without NGF, $\mathrm{n}=18$; with NGF, $\mathrm{n}=22$ ).

As expected in the longer migration experiment, Schwann cell migration was substantially farther in all groups when compared with the $72 \mathrm{hr}$ migration distances. Surprisingly, Schwann cells from p75 $+/-$ and $+/+$ embryos did not migrate farther in the presence of NGF (p75 +/- without NGF, $2.98 \pm 0.20 \mathrm{~mm}, n=23$; p75 +/- with NGF, $2.75 \pm 0.13 \mathrm{~mm}, n=22$ ) (Fig. 7B). Schwann cells from the DRG of p75 -/- embryos also do not migrate significantly farther in the presence of NGF (p75 - /- without $\mathrm{NGF}, 3.20 \pm 0.17 \mathrm{~mm}, n=26$; p75 - / - with NGF $3.49 \pm 0.13 \mathrm{~mm}$, $n=30$ ). Although NGF does not appear to affect migration in this assay, addition of NGF appears to qualitatively affect the number of cells adhered to the glass coverslip after removal of the DRG. This was observed in all p75 genotypes. Using one-way ANOVA, there was a statistically significant difference $(p<0.01)$ in Schwann cell migration from the DRG of p $75-/-$ and p $75+/-$ embryos in the presence of NGF. The biological relevance of this difference is not clear because embryonic Schwann cells did not show a statistically significant response to NGF. These experiments suggest that p75 regulates embryonic Schwann cell migration in an NGFindependent manner.

\section{DISCUSSION}

Our data show that p75 is important for the developmental morphology of nerves in the limbs as well as nerves derived from the trigeminal ganglia. In addition, we found that immunoreactivity for Schwann cell marker $\mathrm{S} 100 \beta$ along the developing ophthalmic branch of the TG from p $75-/-$ embryos is decreased or absent in regions. Schwann cell ensheathment of the developing sensory axon bundles was also severely impaired. These observations are supported by in vitro studies showing a decrease in neurite outgrowth and Schwann cell migration from E12.5 DRG of p75 -/embryos. Taken together, these data suggest that p75 plays an important role in axon growth and Schwann cell migration.

Because the p75 mutation affects a wide range of peripheral neurons in adult mice, including sensory neurons (Lee et al., 1992) 


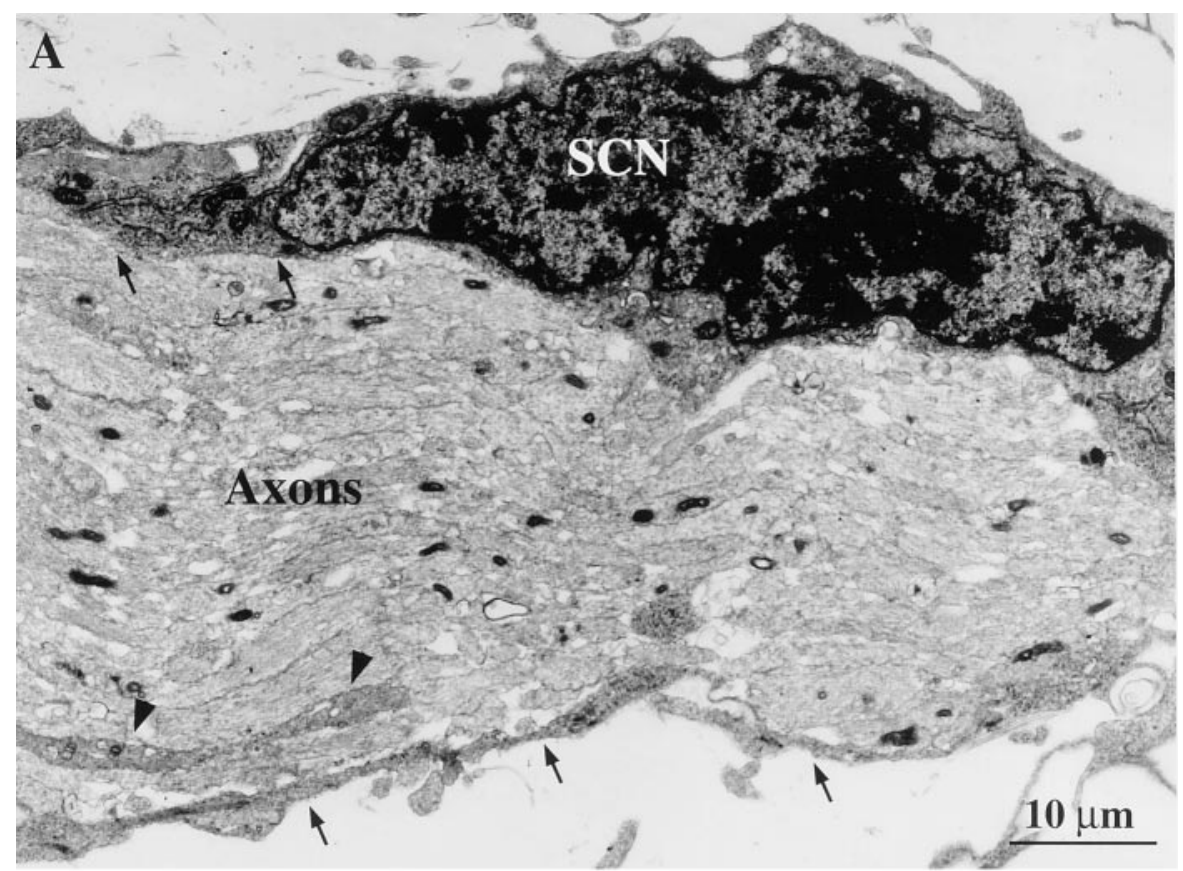

Figure 6. Electron microscopy images of axons innervating the skin above the eye at E13.5 in control and p75 mutant embryos. Sections with the plane of the skin expose a roughly longitudinal view of the axon bundle with associated Schwann cells. Schwann cell nuclei $(S C N)$ and axons are labeled. $A$, In micrograph from control embryo, axon bundle is organized and well defined. Schwann cell cytoplasm makes contact with and ensheaths the axon bundle (arrows). Cytoplasmic processes from Schwann cells also innervate the axon bundle (arrowheads). Scale bars (shown in $A$ and $B$ ): $10 \mu \mathrm{m}$. $B$, In micrograph from $\mathrm{p} 75-/-$ embryos, the axon bundle is thin and disorganized. Schwann cell cytoplasmic processes make few contacts with the axon bundle (arrows), whereas much of the axon bundle is bare of Schwann cell cytoplasmic ensheathment (arrowheads). C, Higher-power magnification of box shown in $B$ shows regions of the axon bundle in contact with Schwann cell cytoplasm (arrows) and regions of the axon bundle without Schwann cell cytoplasm ensheathment (arrowheads). Scale bar, $5 \mu \mathrm{m}$.

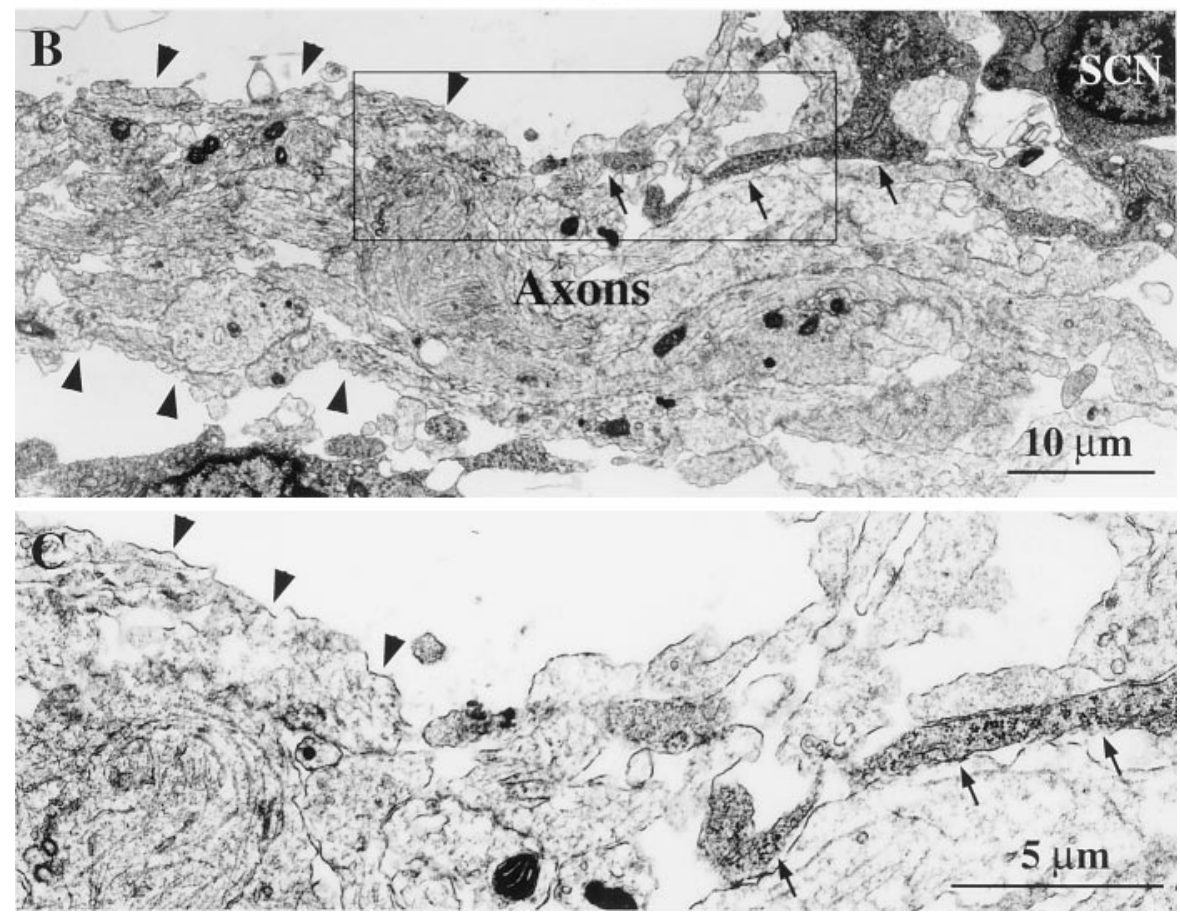

and sympathetic neurons (Lee et al., 1994a), we hypothesized that p75 may be important for aspects of general axon innervation and growth. Our results show that several types of peripheral nerves are indeed severely stunted in the p75 mutant embryo. The aberrant morphology of the p75 peripheral nerves is likely responsible for much of the sensory neuron loss and innervation deficits described in p75 mutant adult mice. The stunted axons in the p75 -/embryos may not receive adequate neurotrophic and morphogenic cues from intermediate and final target fields, thereby resulting in deficiencies in innervation and neuron loss. Further studies to determine the timing of neuronal loss in the DRG of p75 mutant mice and the mechanism of that loss (i.e., programmed cell death) will be required to finally elucidate this point. Our results suggest that the general mechanisms by which p75 supports appropriate peripheral innervation is morphological in nature, involving both axonal growth and arborization.

Several cellular phenomena likely contribute to the effect of p75 on axon growth and morphology, including (1) axonal extension and (2) axonal arborization and branching. In the case of axonal extension, our in vitro results suggest that neurite outgrowth is indeed decreased in p75 $-/-$ embryos. This is also consistent with recent work demonstrating that p75 acts through Rho to stimulate neurite outgrowth (Yamashita et al., 1999). In the case of arbor formation and branching, p75 may modulate these activities through both axon-target field interactions and axon-Schwann cell interactions.

Because p75 is also expressed in the target tissue (Wheeler and Bothwell, 1992), it is reasonable to consider that interaction of axons with the target field may have profound effects on axon morphology. In vitro assays have shown that innervation morphology, either an unbranched extension or an arbor formation, is dependent on the age of the target tissue (Erzurumlu and Jhaveri, 1995). This work indicates that molecular cues within the target tissue direct morphological aspects such as branching. p75 has been 

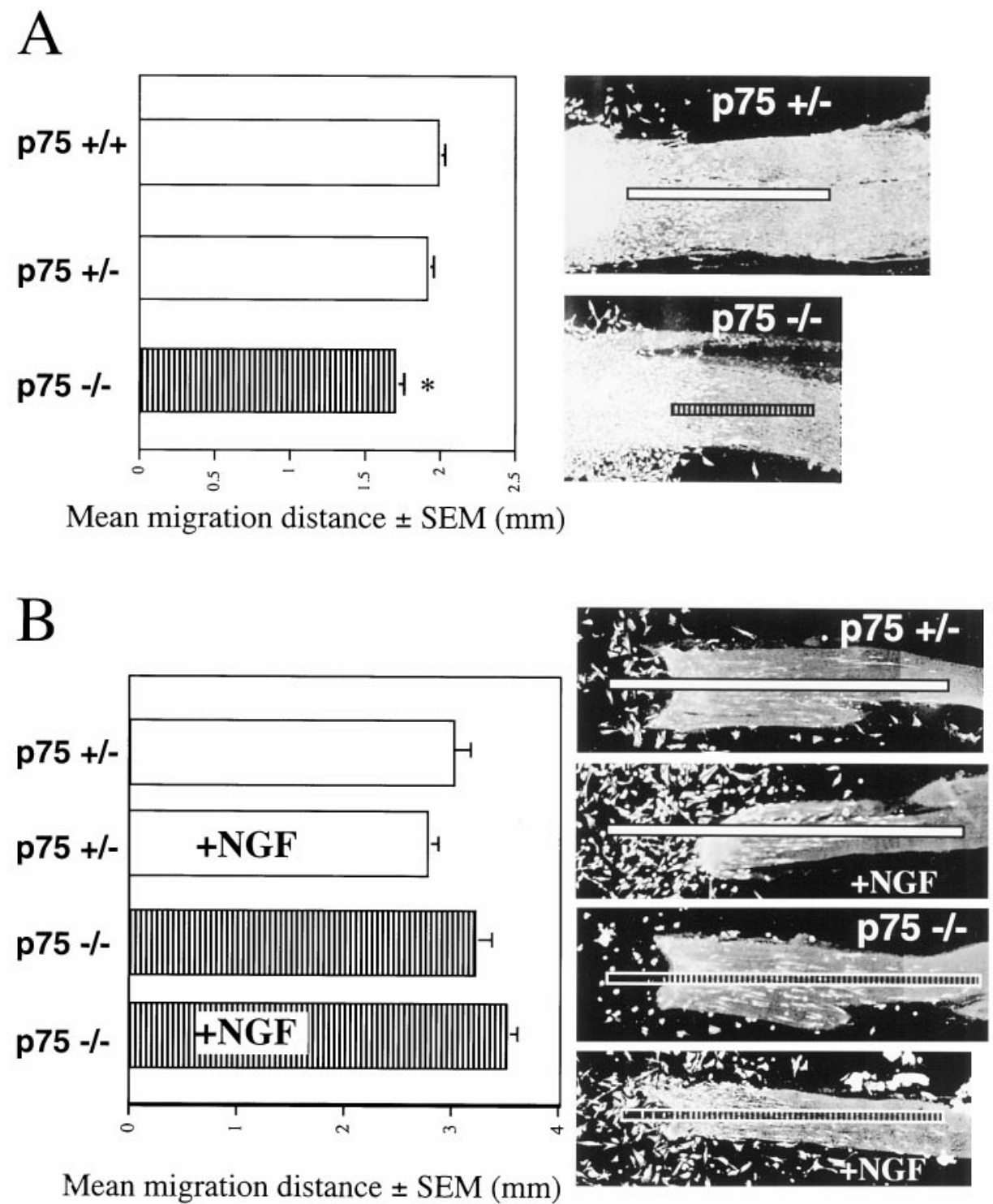

Figure 7. In vitro Schwann cell migration from the DRG of control and p75 -/- embryos. $A$, Bar graph shows mean distance $(\mathrm{mm})$ of Schwann cell migration and SEM in $72 \mathrm{hr}$ DRG cultures from $\mathrm{p} 75+/+,+/-$, and $-/-$ embryos. Migration of Schwann cells from the DRG of p75-/- embryos is significantly lower (asterisk) than migration from both the DRG of $\mathrm{p} 75+/+$ embryos $(p<0.001)$ and the DRG of $75+/-$ embryos $(p=0.01)$. Representative micrographs showing vital dye staining of DRG and Schwann cells along the sciatic nerve are marked with a line demonstrating measurement of Schwann cell migration distance. B, Bar graph shows mean distance $(\mathrm{mm})$ of Schwann cell migration and SEM without or with NGF (10 ng/ $\mathrm{ml})$ in $5 \mathrm{~d}$ cultures from control and p $75-/-$ embryos. Representative micrographs showing vital dye-stained Schwann cells along the sciatic nerve are marked with a line demonstrating measurement of Schwann cell migration distance from original location of the DRG. Micrographs show that NGF-treated cultures from the DRG of both p $75+/-$ and p $75-/-$ embryos have many Schwann cells that are adhered to the Mean migration distance \pm SEM $(\mathrm{mm})$ glass coverslip.

shown to regulate sprouting patterns of sympathetic fibers into the TG (Walsh et al., 1999), thus acting as a target-derived cue for sprouting pattern and organization. These data support the possibility that p75 may act in the target to direct axon morphology and demonstrate the importance of the target in axon morphology. This also raises the possibility that topographically, the stunted axons in $\mathrm{p} 75-/-$ embryos may not be exposed to appropriate levels of target field factors such as neurotrophins, which are known to affect branching (Cohen-Cory and Fraser, 1995; Gallo and Letourneau, 1998; Cohen-Cory, 1999; Lom and Cohen-Cory, 1999).

Differential innervation by TG (the ophthalmic branch vs the maxillary branch) to its targets in the p75 $-/-$ embryo suggests that p75 has variable effects on axon-target interactions. Expression studies indicate that p75 is expressed throughout the TG (Yan and Johnson, 1988; Hallböök et al., 1990); therefore, uneven expression of p75 in the neurons of the TG is likely not responsible for the differential loss of innervation. Differential loss of target innervation has previously been found in the p75 mutant mice, including loss of sympathetic innervation to the lateral but not medial footpads (Lee et al., 1994a) and loss of proprioceptive innervation to the soleus muscle but not the fast hindlimb muscles (Fan et al., 1999). These data suggest that differential effects on target innervation are most likely explained by differences in the molecular cues in the target tissue supporting innervation. p75 may also contribute to aspects of axon extension, branching, and axontarget interaction mediated by Schwann cells.
Our finding that $\mathrm{p} 75$ regulates Schwann cell migration in vitro, affects the distal localization of S100 $\beta$-immunoreactive Schwann cells in vivo, and is important for Schwann cell cytoplasmic ensheathment of the growing axon bundle suggests that p75 plays an important role in Schwann cell development and Schwann cellmediated axonal growth. Several studies indicate that Schwann cells are important in axonal growth and morphology (Zimmermann and Sutter, 1983; Bixby et al., 1988; Jessen and Mirsky, 1991). Mice deficient for tyrosine kinase receptors erbB2 (Morris et al., 1999) and erbB3 (Riethmacher et al., 1997) have severe deficits of peripheral innervation and a corresponding lack of Schwann cells in the periphery. Schwann cells in these mutants failed to migrate farther than the most proximal regions of the DRG nerve root. In vitro, a decrease in neurite outgrowth from embryonic DRG of erbB2 mutants could be rescued by the addition of wild-type Schwann cells to the culture (Morris et al., 1999). These results suggest a direct link between Schwann cell migration and axonal outgrowth. We deduce that the defect in Schwann cell migration from DRG of p75 - /- embryos may also contribute to the observed deficits in axonal outgrowth.

Although NGF has been shown to stimulate Schwann cell migration from neonatal rat DRG (Anton et al., 1994), we show here that in embryonic mouse DRG, NGF is not sufficient to alter Schwann cell migration. This surprising result is supported by our experiments on transected sciatic nerves and work showing that the culture conditions used here are capable of supporting migration 
induction (Morris et al., 1999). The increase in Schwann cell migration from neonatal rat DRG on transected sciatic nerves (Anton et al., 1994) was not observed in our embryonic DRG cultures on transected sciatic nerves (data not shown). We have also shown that our culture conditions can support migration from neonatal murine DRG in response to neuregulin (Morris et al., 1999), similar to the response seen in neonatal rat DRG (Mahanthappa et al., 1996).

The lack of NGF-induced migration response from embryonic DRG suggests that either (1) NGF has no affect on embryonic Schwann cell migration or (2) other factors or substrates not present in the culture assay are required for the NGF response. Interestingly, neuregulin, the ligand for the erbB2 and erbB3 heterodimer, is also unable to elicit a migration response in embryonic Schwann cells, despite the fact that deletion of the erbB2 gene clearly leads to a decrease in migration and neuregulin can induce migration from neonatal DRG (Morris et al., 1999). A trend emerges in which neonatal mouse Schwann cells can respond to the ligands NGF and neuregulin, whereas migration of embryonic Schwann cells is independent of these ligands. These data indicate a distinct developmental difference between embryonic and neonatal Schwann cells.

Taken together, the decrease in Schwann cell migration from the DRG of p75 $-/-$ and erbB2 -/- embryos implies that these receptors impart some intrinsic migration capabilities on Schwann cells. Therefore, the role of p75 in Schwann cell migration is likely more complex than a simple NGF migration response.

Decreased $\mathrm{S} 100 \beta$ immunoreactivity along the developing TG axons in the skin further advocates the importance of p75 in Schwann cell function. It is not clear whether this decrease results from a lower expression within a given cell, a decreased number of Schwann cells, particularly if they fail to migrate, or a combination of both scenarios. In the first case, we must consider the significance of $\mathrm{S} 100 \beta$, not only as a marker but as a calcium-modulating protein involved in many cellular activities: cell-cell communication, cell growth, cell shape, and signal transduction (Zimmer et al., 1995). Decreased $\mathrm{S} 100 \beta$ staining may be secondary to a developmental delay in the Schwann cells of p75 - /- embryos or a primary effect of $\mathrm{p} 75$ on regulation of $\mathrm{S} 100 \beta$ expression. However, electron microscopy of embryonic axons and their associated Schwann cells suggests that the number of Schwann cells is indeed decreased along developing axons. These ultrastructural studies also indicate a severe disruption in Schwann cell cytoplasmic ensheathment of the developing axon.

The results presented here demonstrate that p75 is a multifunctional regulator of embryonic neural and Schwann cell development. p75 is required for appropriate axonal morphology and outgrowth and for complete Schwann cell migration. Future studies using cell type-specific gene knockout technologies will be required to understand how p75 expression in the neurons, Schwann cells, and target tissues contributes to the axon and Schwann cell defects.

\section{REFERENCES}

Anton ES, Weskamp G, Reichardt LF, Matthew W (1994) Nerve growth factor and its low-affinity receptor promote Schwann cell migration. Proc Natl Acad Sci USA 91:2795-2799.

Bamji SX, Majdan M, Pozniak CD, Belliveau DJ, Aloyz R, Kohn J, Causing CG, Miller FD (1998) The p75 neurotrophin receptor mediates neuronal apoptosis and is essential for naturally occurring sympathetic neuron death. J Cell Biol 140:911-923.

Barker PA, Shooter EM (1994) Disruption of NGF binding to the lowaffinity neurotrophin receptor p75 reduces NGF binding to trkA on PC12 cells. Neuron 13:203-215.

Barrett GL, Bartlett PF (1994) The p75 NGF receptor mediates survival or death depending on the stage of sensory neuron development. Proc Natl Acad Sci USA 91:6501-6505.

Bergmann I, Priestley JV, McMahon SB, Bröcker E-B, Toyka KV, Koltzenburg M (1997) Analysis of cutaneous sensory neurons in transgenic mice lacking the low affinity neurotrophin receptor p75. Eur J Neurosci 9:18-28.

Bhattacharyya A, Brackenbury R, Ratner N (1994) Axons arrest the migration of Schwann cell precursors. Development 120:1411-1420.

Bixby JL, Lilien J, Reichardt LF (1988) Identification of the major pro- teins that promote neuronal process outgrowth on Schwann cells in vitro. J Cell Biol 107:353-361.

Bothwell M (1991) Keeping track of neurotrophin receptors. Cell 65:915-918.

Brennan C, Rivas-Plata K, Landis SC (1999) The p75 neurotrophin receptor influences neurotrophin-3 responsiveness of sympathetic neurons in vivo. Nat Neurosci 2:699-705.

Byers MR (1990) Segregation of NGF receptor in sensory receptors, nerves and local cells of teeth and periodontium demonstrated by EM immunocytochemistry. J Neurocytol 19:765-775.

Carter BD, Kaltschmidt C, Kaltschmidt B, Offenhauser N, Bohm-Matthaei R, Baeuerle PA, Barde Y-A (1996) Selective activation of NF- $\kappa$ B by nerve growth factor through the neurotrophin receptor p75. Science 272:542-545.

Casaccia-Bonnefil P, Carter B, Dobrowsky RT, Chao MV (1996) Death of oligodendrocytes mediated by the interaction of nerve growth factor with its receptor p75. Nature 383:716-719.

Chao MV (1992) Neurotrophin receptors: a window into neuronal differentiation. Neuron 9:583-593.

Cohen-Cory S (1999) BDNF modulates, but does not mediate, activitydependent branching and remodeling of optic axon arbors in vivo. J Neurosci 19:9996-10003.

Cohen-Cory S, Fraser SE (1995) Effects of brain-derived neurotrophic factor on optic axon branching and remodelling in vivo. Nature 378:192-196.

Davies AM, Lee KF, Jaenisch R (1993) p75-deficient trigeminal sensory neurons have an altered response to NGF but not to other neurotrophins. Neuron 11:565-574.

Dobrowsky R, Jenkins GM, Hannun Y (1995) Neurotrophins induce sphingomyelin hydrolysis. J Biol Chem 270:22135-22142.

Erzurumlu RS, Jhaveri S (1995) Target influences on the morphology of trigeminal axons. Exp Neurol 135:1-16.

Fan G, Jaenisch R, Kucera J (1999) A role for p75 receptor in neurotrophin-3 functioning during the development of limb proprioception. Neuroscience 90:259-268.

Frade JM, Rodriguez-Tebar A, Barde Y-A (1996) Induction of cell death by endogenous nerve growth factor through its p75 receptor. Nature 383:166-168.

Fundin BT, Silos-Santiago I, Ernfors P, Fagan AM, Aldskogius H, DeChiara TM, Phillips HS, Barbacid M, Yancopoulos GD, Rice FL (1997) Differential dependency of cutaneous mechanoreceptors on neurotrophins, trk receptors, and p75 LNGFR. Dev Biol 190:94-116.

Gallo G, Letourneau PC (1998) Localized sources of neurotrophins initiate axon collateral sprouting. J Neurosci 18:5403-5414.

Hallböök F, Ayer-LeLievre C, Ebendal T, Persson H (1990) Expression of nerve growth factor receptor mRNA during early development of the chicken embryo: emphasis on cranial ganglia. Development 108:693-704.

Hantzopoulos PA, Suri C, Glass DJ, Goldfarb MP, Yancopoulos GD (1994) The low affinity NGF receptor, p75, can collaborate with each of the Trks to potentiate functional responses to the neurotrophins. Neuron 13:187-201.

Huber LJ, Chao MV (1995) A potential interaction of p75 and trkA NGF receptors revealed by affinity crosslinking and immunoprecipitation. J Neurosci Res 40:557-563.

Jessen KR, Mirsky R (1991) Schwann cell precursors and their development. Glia 4:185-194.

Kaplan DR, Miller FD (1997) Signal transduction by the neurotrophin receptors. Curr Opin Cell Biol 9:213-221.

Lee K-F, Li E, Huber LJ, Landis SC, Sharpe AH, Chao MC, Jaenisch R (1992) Targeted mutation of the gene encoding the low affinity NGF receptor p75 leads to deficits in the peripheral sensory nervous system. Cell 69:737-749.

Lee K-F, Bachman K, Landis S, Jaenisch R (1994a) Dependence on p75 for innervation of some sympathetic targets. Science 263:1447-1449.

Lee K-F, Davies AM, Jaenisch R (1994b) p75-deficient embryonic dorsal root sensory and neonatal sympathetic neurons displayed decreased sensitivity to NGF. Development 120:1027-1033.

Lom B, Cohen-Cory S (1999). Brain-derived neurotrophic factor differentially regulates retinal ganglion cell dendritic and axonal arborization in vivo. J Neurosci 19:9928-9938.

Mahanthappa NK, Anton ES, Matthew WD (1996) Glial growth factor 2, a soluble neuregulin, directly increases Schwann cell motility and indirectly promotes neurite outgrowth. J Neurosci 16:4673-4683.

McAllister AK, Katz LC, Lo DC (1999) Neurotrophins and synaptic plasticity. Annu Rev Neurosci 22:295-318.

Morris JK, Lin W, Hauser C, Marchuk Y, Getman D, Lee K-F (1999) Genetic rescue of cardiac defect in erbB2 null mutant mice reveals essential roles of erbB2 in development of the peripheral nervous system. Neuron 23:273-283.

Rabizadeh S, Oh J, Zhong L-T, Yang J, Bitler CM, Butcher LL, Bredesen DE (1993) Induction of apoptosis by the low-affinity NGF receptor. Science 261:345-348.

Rice FL, Albers KM, Davis BM, Silos-Santiago I, Wilkinson GA, LeMaster AM, Ernfors P, Smeyne RJ, Aldskogius H, Phillips HS, Barbacid M, DeChiara TM, Yancopoulos GD, Dunne CE, Fundin BT (1998) Differential dependency of unmyelinated and A delta epidermal and upper 
dermal innervation on neurotrophins, trk receptors, and p75LNGFR. Dev Biol 198:57-81.

Riethmacher D, Sonnenberg-Riethmacher E, Brinkmann V, Yamaai T, Lewin GR, Birchmeier C (1997) Severe neuropathies in mice with targeted mutations in the ErbB3 receptor. Nature 389:725-730.

Rodríguez-Tébar A, Dechant G, Barde Y-A (1990) Binding of brainderived neurotrophic factor to the nerve growth factor receptor. Neuron 4:487-492.

Rodríguez-Tébar A, Dechant G, Götz R, Barde Y-A (1992) Binding of neurotrophin-3 to its neuronal receptors and interactions with nerve growth factor and brain-derived neurotrophic factor. EMBO J 11:917-922.

Sandrock Jr AW, Matthew WD (1987) Identification of a peripheral nerve neurite growth-promoting activity by development and use of an in vitro bioassay. Proc Natl Acad Sci USA 84:6934-6938.

Snider WD (1994) Functions of the neurotrophins during nervous system development: what the knockouts are teaching us. Cell 77:627-638.

Taniuchi M, Clark HB, Schweitzer JB, Johnson EM Jr (1988) Expression of nerve growth factor receptors by Schwann cells of axotomized peripheral nerves: ultrastructural location, suppression by axonal contact, and binding properties. J Neurosci 8:664-681.

Tuttle R, Matthew WD (1991) An in vitro bioassay for neurite growth using cryostat sections of nervous tissue as a substratum. J Neurosci Med 39:193-202.

Twiss JL, Wada HG, Fok KS, Chan SDH, Verity AN, Baxter GT, Shooter EM, Sussman HH (1998) Duration and magnitude of nerve growth factor signaling depend on the ratio of $\mathrm{p} 75^{\mathrm{LNTR}}$ to TrkA. J Neurosci Res $51: 442-453$.

Verdi JM, Birren S, Ibanez CF, Persson H, Kaplan DR, Benedetti M, Chao M, Anderson D (1994) p75 LNGFR regulates Trk signal transduction and NGF-induced neuronal differentiation in MAH cells. Neuron 12:733-745.
Walsh GS, Krol KM, Kawaja MD (1999) Absence of the p75 neurotrophin receptor alters the pattern of sympathosensory sprouting in the trigeminal ganglia of mice overexpressing nerve growth factor. J Neurosci 19:258-273.

Wheeler EF, Bothwell M (1992) Spatiotemporal patterns of expression of NGF and the low-affinity NGF receptor in rat embryos suggest functional roles in tissue morphogenesis and myogenesis. J Neurosci 12:930-945.

Woldeyesus MT, Britsch S, Riethmacher D, Xu L, SonnenbergRiethmacher E, Abou-Rebyeh F, Harvey R, Caroni P, Birchmeier C (1999) Peripheral nervous system defects in erbB2 mutants following genetic rescue of heart development. Genes Dev 13:2538-2548.

Wolf DE, McKinnon CA, Daou M-C, Stephens RM, Kaplan DR, Ross AH (1995) Interaction with TrkA immobilizes gp75 in the high affinity nerve growth factor receptor complex. J Biol Chem 270:2133-2138.

Wright DE, Snider WD (1995) Neurotrophin receptor mRNA expression defines distinct populations of neurons in rat dorsal root ganglia. J Comp Neurol 351:329-338.

Yamashita T, Tucker KL, Barde Y-A (1999) Neurotrophin binding to the p75 receptor modulates Rho activity and axonal outgrowth. Neuron 24:585-593.

Yan Q, Johnson Jr EM (1988) An immunohistochemical study of the nerve growth factor receptor in developing rats. $J$ Neurosci 8:3481-3498.

Zimmer DB, Cornwall EH, Landar A, Song W (1995) The S100 protein family: history, function, and expression. Brain Res Bull 37:417-429.

Zimmermann A, Sutter A (1983) $\beta$-Nerve growth factor $(\beta N G F)$ receptors on glial cells. Cell-cell interaction between neurons and Schwann cells in cultures of chick sensory ganglia. EMBO J 2:879-885. 